\title{
PENGARUH TINGKAT PENDIDIKAN DAN JENIS KELAMIN PETERNAK TERHADAP TINGKAT PRODUKSI BABI (STUDI KASUS DI MANOKWARI, PAPUA BARAT INDONESIA)
}

\author{
The effect of Farmer Education Level and Gender on the Level of Pig Production \\ (Case Study in Manokwari, West Papua Indonesia)
}

\author{
Deny A. Iyai' ${ }^{1}$, Stepanus Pakageㄹ, Agustinus G. Murwanto1, Maria Arim², Dwi Nurhayati1', M. \\ Lily Orisu ${ }^{3}$, Isti Widayati ${ }^{1}$, dan Hieronymus Yohanes Rumfaan ${ }^{1}$ \\ ${ }^{1}$ Faculty of Animal Science, Universitas Papua \\ ${ }^{2}$ Faculty of Agriculture, Universitas Papua \\ ${ }^{3}$ Faculty of Economics and Business, Universitas Papua \\ E-mail: da.iyai@yahoo.com
}

\begin{abstract}
INTISARI
Tujuan dari penelitian ini adalah untuk memahami pengaruh tingkat pendidikan dengan jenis kelamin pada produksi peternakan babi, kasus khusus di Manokwari Papua Barat-Indonesia. Studi lapangan dilakukan di Kabupaten Manokwari yang melibatkan enam Kabupaten. Responden dari 49 petani yang dipilih dipandu oleh ekstensi lokal yang dipilih dari 15 desa. Analisis situasi partisipatif digunakan untuk mendekati petani babi dengan menggunakan kuesioner. Analisis varian umum model linear digunakan. Semua data dimasukkan dalam Excel dan dianalisis menggunakan SPPS versi 10.0. Hasil kajian menunjukkan bahwa interaksi antara pendidikan dan gender menunjukkan pengaruh yang signifikan terhadap anggota rumah tangga dan pendapatan. Wanita dengan pendidikan yang memadai akan memberikan penghasilan yang lebih baik dibandingkan dengan pria. Memahami pengaruh interaksi tingkat pendidikan dan gender akan memungkinkan peternak meningkatkan produktivitas babi mereka dalam skala dan waktu.
\end{abstract}

Kata kunci: Gender, Pendidikan, Petani Perempuan dan Laki-Laki, Sistem Pemeliharaan Babi

\begin{abstract}
The aim of this research was to understand the effect of educational level of gender types on pig farming production, a special case in Manokwari West Papua-Indonesia. The field study was done in Manokwari regency involved six districts. The respondents of 49 farmers chosen guided by local extensions selected from 15 villages. The participatory situation analysis employed to approach pig farmers by using questionnaire. A General Linear Model analysis of variances was used. All data were entered in Excel and analyzed using SPPS version 10.0. The conclusion that interaction between education and gender occur on household member and income earn. The female with adequate education will provide better income than the male. Understanding interaction effect of education level and gender will enable farmers to improve their pig productivities on scales and time.
\end{abstract}

Keywords: Pigs Keeping Systems, Education, Gender, Female and Male Farmers

\section{INTRODUCTION}

Pig production systems on tropical agroecosystems of each country reared are varying. This pig production systems depend on resources, in particular feeds such as crops (Muhanguzi et al., 2012) residues and other potential edible plants (Terry and Khatri,
2009; Plaza-bonilla et al., 2017; Uwizeye et al., 2019) and climate elements. Areas where available with crops can have certain animal production systems.

Shapes and alternation of pig production systems tend to be determined by climates (Wabacha et al., 2004) and other important relevant factors such as constraints and 
limitation faced by farmers (Iyai dan Yaku, 2015; Iyai et al., 2018). Wet and dry seasons tend to shape livestock production systems. Many agro-ecological components have identified contributed in performing livestock production systems in Asia (Devendra, 2007). Several classifications of animal agriculture and definitions can be referred in the articles of Devendra and Thomas (2002) and Kruska et al. (2003).

Other typical agro-ecological elements can be classified into island, coastal, and lowland zones. Region such Indonesia has many agro-ecological zones (Devendra and Thomas, 2002; Iyai, 2011). They are the recognised as typical agro-ecological components. Many livestock and crops production systems are severely and evidently depended on these components. However, many production systems shaped by interaction of education (Iyai et al., 2013; Eliakunda et al., 2015) and gender (Terry and Khatri, 2009; Phiri, 2012; Camerlink and Turner, 2017) are rarely studied and lagged behind of information.

Its effects on livestock production systems were studied quite often on ruminants, such as cattle, dairy cattle, goat, and sheep (Ayoade et al., 2009; Smith, 2010; Aldosari, 2018). In the other hand, another livestock commodity which has prospect is pigs. Region where pigs are farmed in Indonesia are scared and limited. North Sumatera, Borneo, Bali, North Sulawesi, Molucca, Flores and Papua are dependent on this animal agriculture (Pattiselanno et al., 2014; Widayati et al., 2018).

Papua has several recognized agroecological zones. Similar to other Indonesian regions, islands, and mainland are clearly separated. These effects have been attached by the knowledge and experience of Papuan farmers using different agro-ecological zones. One of their main livelihoods is raising pigs (Iyai, 2008). Iyai and Yaku (2015) had classified pig keeping systems into four systems. Other important Papuan livelihoods were farming, fishing, hunting, and gathering and in few numbers were working as public state officers.

Ethnics of Papuan lived at coastal, islands (big and small islands), lowland and highland. They pig farming tethered and benefits the various agro-ecological zones had shaped the production of pigs. However, its typical and features of these zones were lagging behind. Therefore, the aim of this research was to gain knowledge on interaction effect between education level and gender on pig production in Manokwari, West Papua, Indonesia.

\section{MATERIALS AND METHODS}

\section{Study Sites}

The field study was done in Manokwari regency and involved six districts, i.e. Northern Manokwari district, Eastern Manokari district, Western Manokwari district, Warmare district, Prafi district, and Masni district (Figure 1). Manokwari regency, which has a total area of $14,445 \mathrm{~km}^{2}$ and possesses a population of around 161,000 inhabitants with a density of 11,51 inhabitants $\mathrm{km}^{-1}$, is located at $132^{\circ} 30^{\prime}-134^{\circ} 45^{\prime}$ East Meridian and $0^{\circ} 20^{\prime}$ - $2^{\circ} 25^{\prime}$ South latitude. Manokwari has relatively dense population of around 228 inhabitants per $\mathrm{km}^{2}$.

The population in Manokwari is growing in both urban and rural areas, especially in transmigrating areas, such as Prafi and Masni districts. Respondents chosen were guided by local extensions officers, originated from 15 villages. In urban areas selected farmers originated from Anggrem, Borobudur, Fanindi, Wosi, Amban, and Susweni villages, while in rural areas selected farmers origined at Tanah Merah, Nimbai, Waseki, Aimasi, Mokwan, Mimbowi, SP-8 Masni, Bremi, and Warbefor villages.

Three urban villages are Anggrem, Fanindi, and Wosi, were located on coastal areas of Manokwari as well as the two rural 
villages, i.e. Bremi and Warbefor, which are located in the Northern coastal line of Manokwari. Anggrem, Fanindi, and Wosi are located at less than $5 \mathrm{~m}$ above sea level. Amban and Susweni are located at $110 \mathrm{~m}$ above sea level.
The rural villages Bremi and Warbefor, are located less than $5 \mathrm{~m}$ above sea level. While most villages in Prafi valley, such as Tanah Merah, Waseki, Nimbai, Aimasi, Mokwan, Mimbowi and SP-8 are located at about 20 to $25 \mathrm{~m}$ above sea level.

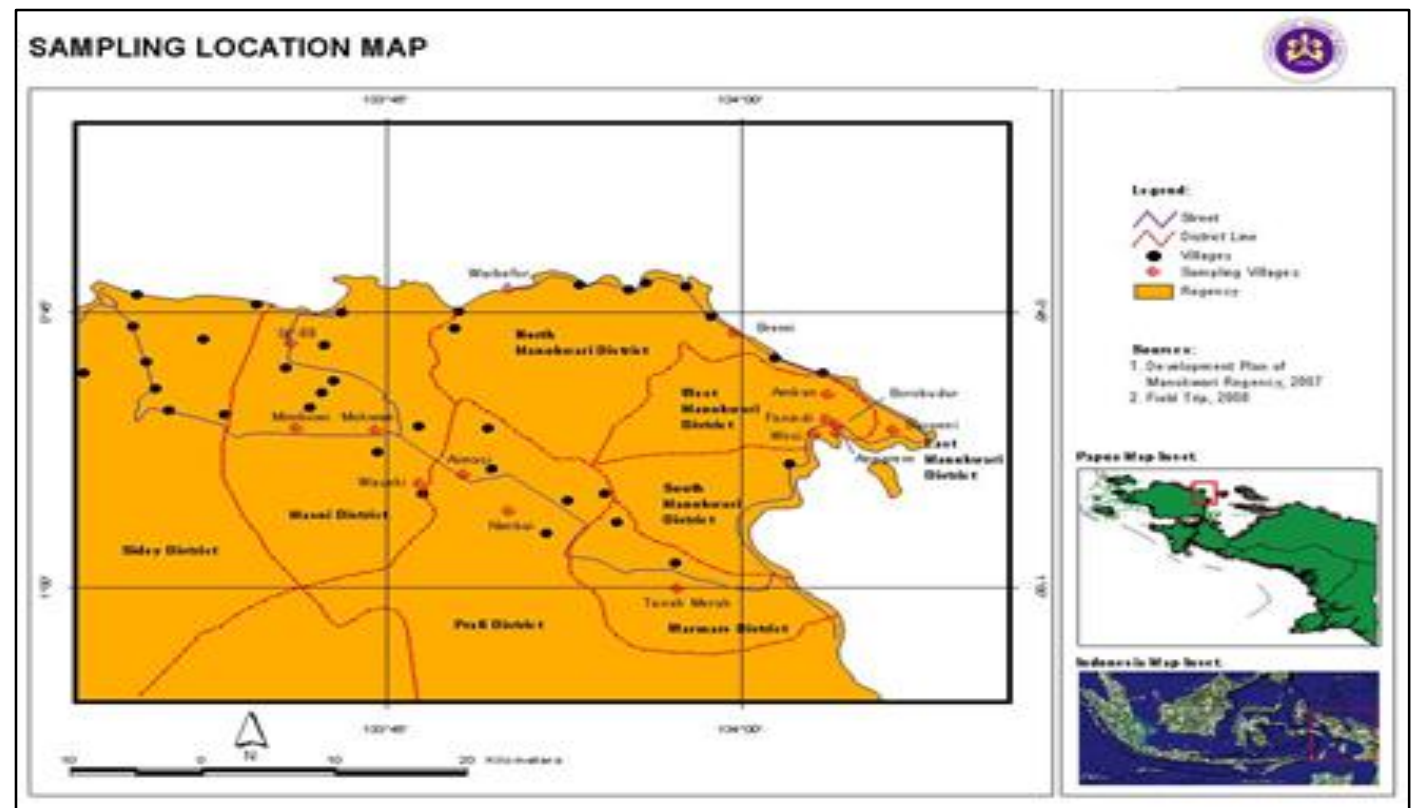

Figure 1. Study site location done in several urban and rural areas of Manokwari.

\section{Research Approach and Parameters}

Participatory situation analysis was employed to approach selected and participated 49 pig farmers. From those farmers, 21 households had free-ranges, 13 semi-pen (semi intensive), and 15 using pen farms (intensive keeping systems). Urban pig farmers involved 20 households and rural farmers were 29 households. Interviews using questionnaire was done to gather information from all pig farmers. Tropical livestock unit (TLU) of the pigs is 0.25 from body weight.

\section{Statistical Analysis}

The full general linear model of interaction proposed was as followed Yijk $=$ $u+\alpha i+\beta j+(\alpha * \beta) i j+\varepsilon i j k ; \mathrm{i}=1,2,3 ; \mathrm{j}=1,2$; $\mathrm{k}=1, . ., 5$. Where Yijk was pig farming production parameters, $\mathrm{u}$ was intercept, $\alpha \mathrm{i}=$ additive effect of education level $(1=$ no education, 2 = primary schools grouped into junior high and senior high schools, $3=$ university/higher education), $\beta \mathrm{j}$ was gender ( 1 $=$ Male and $2=$ Female), and $\Upsilon=$ interaction between education and gender. The $\varepsilon i j k=$ effect of errors.

A one-way analysis of General Lineal Model used. Classification was based on educational and gender consisted of herd number (in Topical Livestock Unit, TLU), number of piglets, adult pigs. $\mu=$ overall mean, $\alpha i=$ effect of pig keeping systems, and $\varepsilon i j=$ errors with normal distribution, $\mathrm{N}(0, \mathrm{I})$. Qualitative and quantitative data were entered in Excel database 2003. Analysis of data using SPPS version 10.0 was used (Gaspersz, 1991; Ott and Longnecker, 2001; Iyai, 2008).

\section{RESULTS AND DISCUSSION}

\section{Description on Socio-Culture}

Farmers background of the current study (Table 1.) presented household 
members (Hh_mbr), experience, work hours, ethnic, ages, and education level of farmers. The number of household member shown in the range of three to nine persons $\mathrm{hh}^{-1}$. It was typical small to middle number of household member. Highest household member found in interaction of university i.e. $6.55 \pm 3.16$ person/hh (male and female), followed by interaction between uneducated versus gender, i.e. $6.15 \pm 3.37$ person $/ \mathrm{hh}$ and interaction of primary male and female $7.00 \pm 0.00$ person/hh. keeping systems and was in urban agro-ecological areas $(7.91 \pm 4.06$ person/hh).

Table 1. Description of Pig Farmers Background

\begin{tabular}{|c|c|c|c|c|c|c|c|c|}
\hline \multirow{3}{*}{ Variables } & \multirow{3}{*}{ Unit } & \multicolumn{2}{|c|}{ No Education } & \multicolumn{2}{|c|}{ Primary } & \multicolumn{2}{|c|}{ University } & \multirow{3}{*}{ Sig } \\
\hline & & Male & Female & Male & Female & Male & Female & \\
\hline & & $\dot{\mathrm{x}} \pm$ SEM & $\dot{\mathrm{x}} \pm$ SEM & $\dot{\mathrm{x}} \pm$ SEM & $\dot{\mathrm{x}} \pm$ SEM & $\dot{\mathrm{x}} \pm$ SEM & $\dot{\mathrm{x}} \pm$ SEM & \\
\hline Hh_mbr & Head & $6.15 \pm 3.37$ & $4.33 \pm 1.53$ & $6.06 \pm 2.86$ & $7.00 \pm 0.00$ & $6.55 \pm 3.16$ & $6.55 \pm 3.16$ & $*$ \\
\hline Experience & Year & $25.05 \pm 14.02$ & $0.63 \pm 0.32$ & $25.46 \pm 14.31$ & $10.00 \pm 00.00$ & $23.78 \pm 19.48$ & $23.78 \pm 19.48$ & ns \\
\hline Work_Hrs & Hour & $1.87 \pm 0.92$ & $2.67 \pm 0.58$ & $1.75 \pm 1.08$ & $1.50 \pm 0.00$ & $1.50 \pm 0.50$ & $1.50 \pm 0.50$ & ns \\
\hline Age & Year & $45.85 \pm 12.75$ & $47.67 \pm 2.51$ & $46.00 \pm 8.44$ & $58.00 \pm 00.00$ & $40.78 \pm 16.54$ & $40.78 \pm 16.54$ & ns \\
\hline Locations & & $1.30 \pm 1.49$ & $1.69 \pm 0.04$ & $1.57 \pm 0.49$ & $1.29 \pm 0.53$ & $1.20 \pm 0.78$ & $1.23 \pm 0.45$ & ns \\
\hline Ethnic & & $1.20 \pm 0.41$ & $1.54 \pm 0.52$ & $1.25 \pm 0.45$ & $1.00 \pm 0.00$ & $1.00 \pm 0.00$ & $1.20 \pm 0.41$ & ns \\
\hline
\end{tabular}

*significant difference $\mathrm{P}<0.05$. ns: not significant, Hh_mbr = household members, work_Hrs = work hours

Several indicators found no significant difference $(\mathrm{P}>0.05)$ on interaction of education versus gender on experience (Figure. 3), workhours (Figure. 4), ages of farmers (Figure. 5), location and ethnics. However, in general experiences, higher experiences shown by farmers male farmers, i.e. university male and female $(23.78 \pm 19.48)$, followed by primary male $(25.46 \pm 14.31 \mathrm{yr} / \mathrm{hh})$, male with no education background $25.05 \pm 14.02 \mathrm{yr} / \mathrm{hh}$ ).

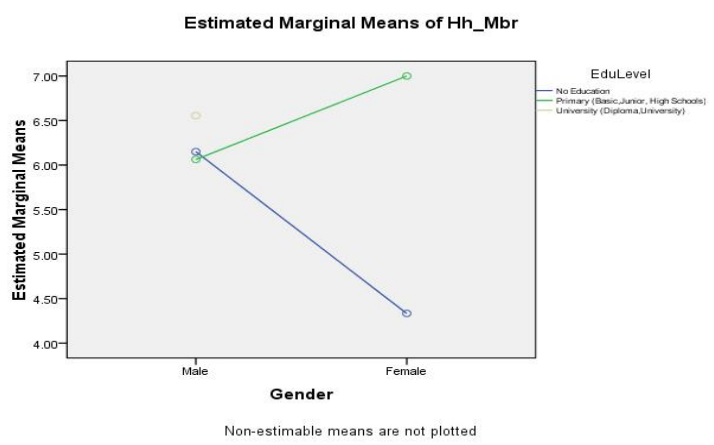

Figure. 2. Interaction effect of education level and gender on household member.

Work hours that we found shown less than 4 hours a day. It seems that work hours spent by pig farmers in these interaction of education versus gender was too short. Higher workhours spent was in female with no education, i.e. $2.67 \pm 0.58 \mathrm{hr} /$ day, followed by male on no education $(1.87 \pm 0.92 \mathrm{hr} /$ day $)$, male on primary education, i.e. $1.75 \pm 1.08$ $\mathrm{hr} /$ day, and university versus gender, i.e. $1.50 \pm 0.50 \mathrm{hr} /$ day.

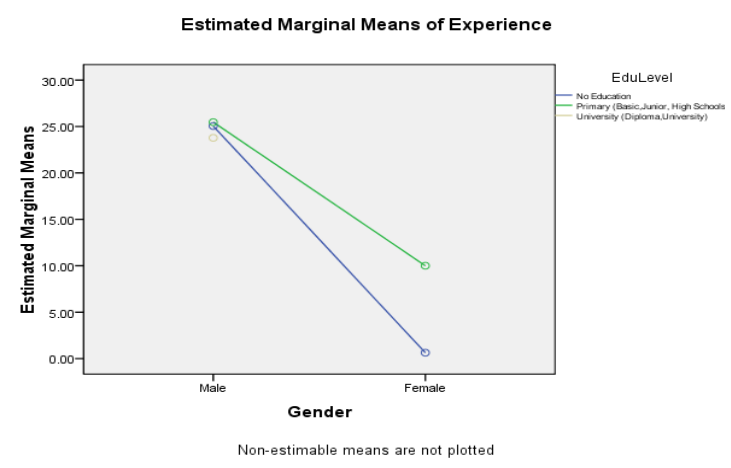

Figure. 3. Interaction effect of education level and gender on experiences.

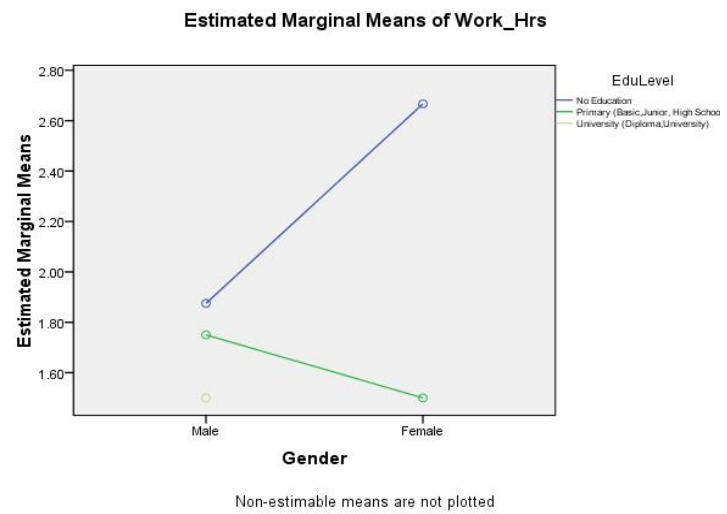

Figure. 4. Interaction effect of education level and gender on work hours. 
Experiences of a farmers will then be resulted from informal education and how farmers tethered their farming business (Kanis et al., 2003; Lassen et al., 2006; Boogaard et al., 2011; de Greef et al., 2011; Correia-Gomes et al., 2017; Fynbo and Jensen, 2018). Another case found on work hours that the work hours between education level and gender had weak interaction.

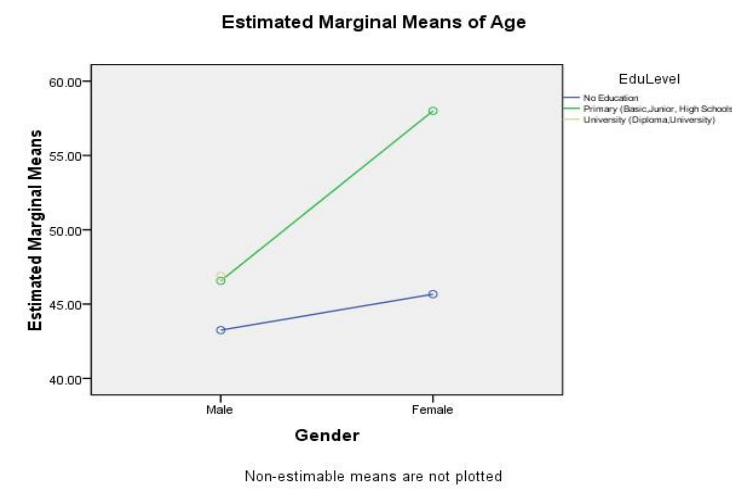

Figure. 5. Interaction effect of education level and gender on age.

Location where farming business were established had no interaction effect on education level and gender. It meant that farmers with ranges of education and gender could have similar chances in developing business of pig production. Educating persons based on West Papuan circumstance were dominated by men. In running keeping systems, men were engaging almost all process of pig production cycles.
We found no interaction between education level and gender on ethnicity. It meant that ethnic community that running pig business in Manokwari was still raising dominantly by local Papuan farmers (Widayati et al., 2018). Ages of pig farmers had interaction effect on education level and gender (Terry and Khatri, 2009; Muhanguzi et al., 2012; Eliakunda et al., 2015). Ages determined by education and gender, the more educated a person will be, the more gender equality will be shifted from working allocation, decision makers and powers in deciding actions delivered.

\section{Pigs Production and Economic Traits}

The results of this research seemed that number of pigs kept by farmers was higher than that reported by Iyai dan Yaku (2015) in Manokwari, i.e. only 5 head/household. It seemed that there was an effect and/or interaction of education level with keeping systems. Number of pigs based on tropical livestock unit was then higher ( $>1$ TLU). The see middle mens (retailers) experienced by small-scale pig farmers in Manokwari (Figure. 8). The figure showed no significant interaction between education and gender $(\mathrm{P}>0.05)$. It meant that middle mens could have similar changes to approach farmers for transaction of selling-buying process. The finding of visiting consumers was similar no significant different (Figure. 9).

Table 2. Production and Income Traits of Pigs Keeping Systems

\begin{tabular}{|c|c|c|c|c|c|c|c|c|}
\hline \multirow{3}{*}{ Variables } & \multirow{3}{*}{ Unit } & \multicolumn{2}{|c|}{ No Education } & \multicolumn{2}{|c|}{ Primary } & \multicolumn{2}{|c|}{ University } & \multirow{3}{*}{ Sig. } \\
\hline & & Male & Female & Male & Female & Male & Female & \\
\hline & & $\dot{\mathrm{x}} \pm$ SEM & $\dot{\mathrm{x}} \pm$ SEM & $\dot{\mathrm{x}} \pm$ SEM & $\dot{\mathrm{x}} \pm$ SEM & $\dot{\mathrm{x}} \pm$ SEM & $\dot{\mathrm{x}} \pm$ SEM & \\
\hline No. Pigs & Tail & $7.60 \pm 9.51$ & $16.67 \pm 2.31$ & $7.75 \pm 5.72$ & $9.00 \pm 0.00$ & $6.33 \pm 5.36$ & $6.33 \pm 5.36$ & ns \\
\hline No. TLU & $\mathrm{AU}$ & $1.90 \pm 2.38$ & $4.17 \pm 0.58$ & $1.94 \pm 1.43$ & $2.25 \pm 0.00$ & $1.58 \pm 1.34$ & $1.58 \pm 1.34$ & ns \\
\hline See midd & Frq & $1.20 \pm 0.83$ & $0.67 \pm 0.58$ & $1.56 \pm 0.96$ & $2.00 \pm 0.00$ & $1.22 \pm 0.67$ & $1.22 \pm 0.67$ & ns \\
\hline Visited consume & Frq & $1.25 \pm 1.21$ & $0.33 \pm 0.57$ & $0.75 \pm 0.77$ & $1.00 \pm 0.00$ & $0.89 \pm 0.60$ & $0.89 \pm 0.60$ & ns \\
\hline Litter size & Tail & $6.05 \pm 2.48$ & $7.33 \pm 0.58$ & $5.31 \pm 1.99$ & $7.00 \pm 0.00$ & $5.33 \pm 1.58$ & $5.33 \pm 1.58$ & ns \\
\hline No. Farrowing & Frq & $1.60 \pm 0.50$ & $1.33 \pm 1.15$ & $1.56 \pm 0.63$ & $1.00 \pm 0.00$ & $1.55 \pm 0.53$ & $1.55 \pm 0.53$ & ns \\
\hline Income & IDR & $1.85 \pm 0.67$ & $3.00 \pm 0.00$ & $1.63 \pm 0.62$ & $1.00 \pm 0.00$ & $2.00 \pm 0.00$ & $2.00 \pm 0.00$ & $*$ \\
\hline
\end{tabular}

*significant difference $\mathrm{P}<0.05$, ns: not significant, no. pigs: number of pigs, No. TLU: number of tropical livestock unit., see midd: see middle mens, No. Farrowing: number of farrowing

Litter size of the pigs kept by farmers was expected different due to interaction.
However, the fact was different. The finding showed that no interaction $(\mathrm{P}>0.05)$ was 
found in litter size number. The figure 11 had no effect $(\mathrm{P}>0.05)$ as well on farrowing number per sow/household. The farrowing rate which could achieved by local pig farmers did not differ among pig farmers. It meant that farrowing rate of each a gilt and/or a sow was lower than that expected by the farmers which could get 3 times $\mathrm{y}^{-1}$. The income source found significant difference in interaction between education level and gender $(\mathrm{P}<0.05)$. These was apparently seen that development of pigs keeping systems in West Papua established had linearity with level of education.

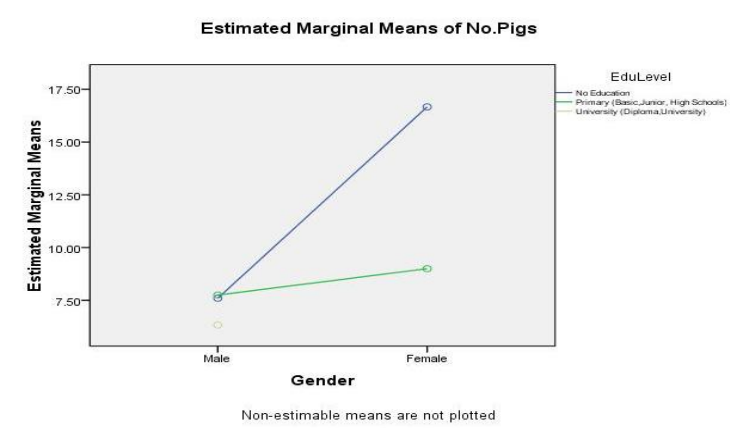

Figure. 6. Interaction effect of education level and gender on pig herds.

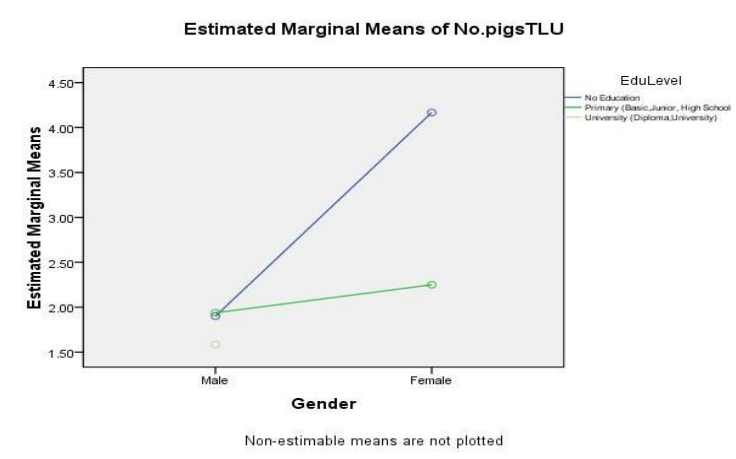

Figure. 7. Interaction effect of education level and gender on tropical livestock unit.

The effect was too small and depended on other factors. Understanding pig production performances will enable decision making getting easier and more precise on selecting pig production traits and broad design on economic efficiency. The number of pigs (herding size) was an indicator explaining living asset that belongs and keeps a live by a farmer (Wabacha et al., 2004; Holt et al., 2019).

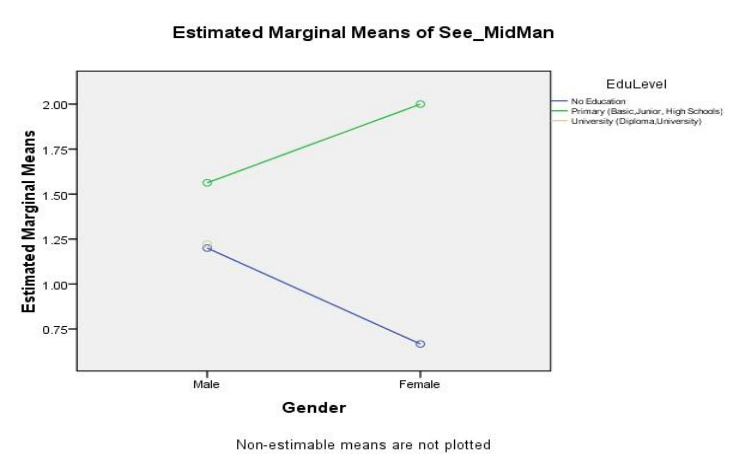

Figure. 8. Interaction effect of education level and gender on seeing middle men.

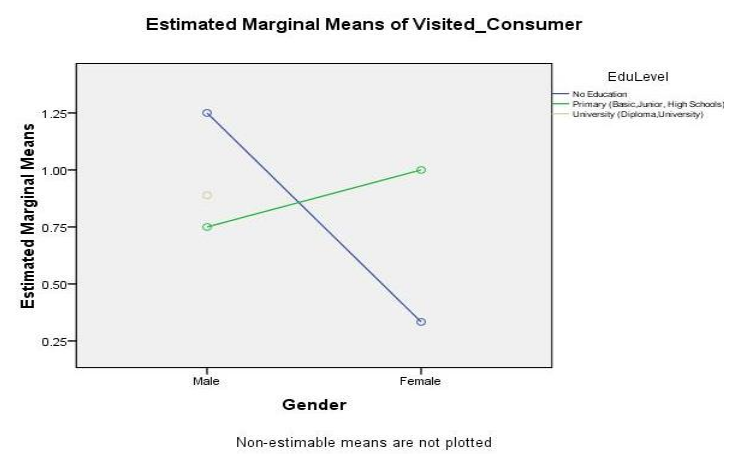

Figure. 9. Interaction effect of education level and gender on visited consumers.

The see middle mens (retailers) experienced by small-scale pig farmers in Manokwari showed no different of interaction between keeping systems with education level. This meant that see middle mens could have similar changes to approach farmers for transaction of selling-buying process. the Litter size of the pigs kept by farmers was expected different due to interaction (Figure. 10).

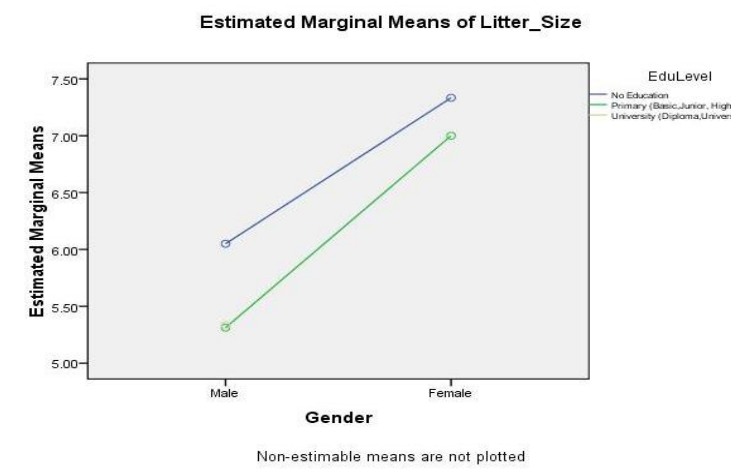

Figure. 10. Interaction effect of education level and gender on litter size. 
However, the fact was different. No interaction was found in litter size number. In average farmers could produce $5.72 \pm 0.40$ head/sow/household. This figure had an effect as well on farrowing number per sow/household. The farrowing rate (Figure. 11) which could be achieved by local pig farmers was $1.58 \pm 0.12$ times/year/sow/ household. This meant that farrowing rate of each a gilt and/or a sow was lower than that expected by the farmers.

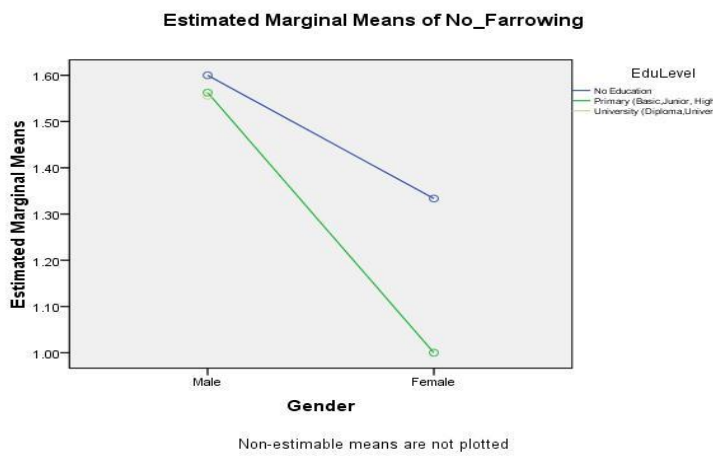

Figure. 11. Interaction effect of education level and gender on farrowing frequency.

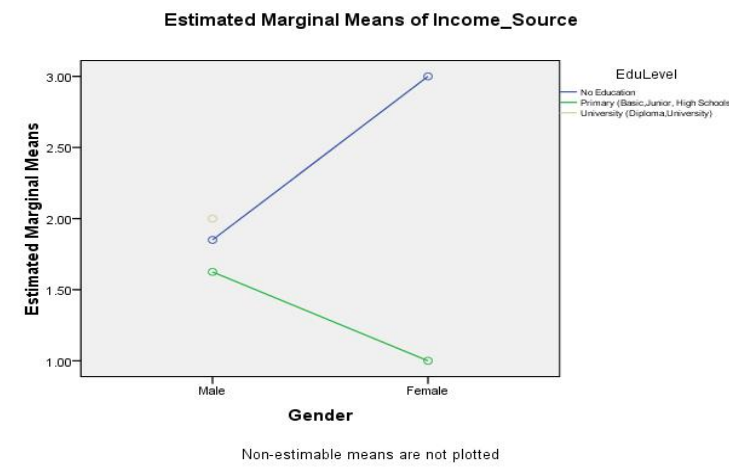

Figure. 12. Interaction effect of education level and gender on income source.

The income source (Figure. 12) determine the performances of keeping systems could sustain or not sustain. The question why we consider education and gender constitute two indicators that has determined the looks of production. We found in other cases and studies that mostly female farmers were more active in following government program by attending meetings, extension program, and etc. The female allocate more time in managing its pig farms than the male farmers.

The middle mens and consumers had free choices and markets in buying the product of meat and life pigs for breeds. The consumers and buyers had free choices in determining pig producers. However, number of pigs (herd size), animal unit, and income had no interaction effects. One interesting phenomenon was that the more herd pigs were raised, the more consumers' farmers could have. They had possibilities in selling a number of pigs and in turn delivering cash for the farmers. Therefore, farmers need to provide good livestock farm management in good manner to reaching big market opportunity. Good livestock farming practices will bring future prospect for the good business of pigs production systems (Kijlstra and Eijck, 2006; Lassen et al., 2006; Rivai, dan Anugrah, 2011; Muhanguzi et al., 2012; Sysak et al., 2012; Holt et al., 2019).

\section{CONCLUSIONS}

The conclusion that interaction between education and gender occur on household member and income earn. The female with adequate education will provide better income than the male. Understanding interaction effect of education level and gender will enable farmers to improve their pig productivities on scales and time.

\section{ACKNOWLEDGMENT}

We thanked staffs of Extension office, Livestock and Veterinary Provincial Office, all households and private enterprises for allowing collecting data and observing the farms, sharing data and information. Statistician of Papua University was grateful for consulting the statistical methods.

\section{REFERENCES}

Aldosari, F.0. 2018. Gender participation in sheep and goat farming in Najran, 
Southern Saudi Arabia. Saudi Journal of Biological Sciences. 25(1): 144-48.

Ayoade, J. A., Ibrahim, H. I., \& Ibrahim, H. Y. 2009. Analysis of women involvement in livestock production in Lafia area of Nasarawa State, Nigeria. Age. 21(30): 31-40.

Boogaard, B.K., L.J.S. Boekhorst, S.J. Oosting, and J.T. Sørensen. 2011. Socio-cultural sustainability of pig production: citizen perceptions in the Netherlands and Denmark. Livestock Science. 140(1-3): 189-200.

Camerlink, I., and S.P. Turner. 2017. Farmers' perception of aggression between growing pigs. Applied Animal Behaviour Science. 192: 42-47.

Correia-Gomes, C., M.K. Henry, H.K. Auty, and G.J. Gunn. 2017. Exploring the role of small-scale livestock keepers for national biosecurity - the pig case. Preventive Veterinary Medicine. 145: 715.

Devendra, C. 2007. Perspectives on animal production systems in Asia. 106(1): 118.

Devendra, C. dan D. Thomas. 2002. Cropanimal systems in Asia: importance of livestock and characterisation of agroecological zones. Agricultural Systems. 71(1-2): 5-15.

Eliakunda, K., F. Lekule, J. Mlangwa, H. Mejer, and S. Thamsborg. 2015. Smallholder pigs production systems in Tanzania. Journal of Agricultural Science and Technology A. 5: 47-60.

Fynbo, L. and C.S. Jensen. 2018. Antimicrobial stigmatization: public health concerns about conventional pig farming and pig farmers experiences with stigmatization. Social Science and Medicine. 201: 1-8.

Gaspersz, V. 1991. Metode Perancangan Percobaan; Untuk Ilmu-Ilmu Pertanian, Ilmu-Ilmu Teknik, dan Biologi. CV. Armico. Bandung.

De Greef, K.H., H.M. Vermeer, H.W.J. Houwers, and A.P. Bos. 2011. Proof of Principle of the comfort class concept in pigs.. experimenting in the midst of a stakeholder process on pig welfare. Livestock Science. 139 (1-2): 172-85.

Holt, H.R., P. Inthavong, K. Blaszak, C. Keokamphe, A. Phongmany, S.D. Blacksell, P.A. Durr. K. Grahamg, J. Allen, B. Donnelly, K. Newberry, D. Grace, S. Alonso, J. Gilbert, and F. Unger. 2019. Production diseases in smallholder pig systems in rural lao PDR. Preventive Veterinary Medicine. 162: 110-116.

Iyai, D.A. 2008. Inovation Possibilities In Pig Keeping System In Manokwari Papua Barat Province Indonesia. Thesis. Wageningen University. Wageningen.

Iyai, D.A., O. Marani, T. Marjen, and L. Usior. 2013. Pig farming performances of three papuan tribes : case study of Byak, Onate and Arfak tribes in Papua Barat. Journal of The Indonesian Tropical Animal Agriculture. 38(1): 55-64.

Iyai, D.A. and A. Yaku. 2015. Identifikasi sistim peternakan di Manokwari, Papua BaratIndonesia Jurnal Peternakan Indonesia. 17 (2): 94-104.

Iyai, D.A. 2011. Comparing characteristics of various agro-ecological zones of pig farming systems; case study of islands, coastal and lowland pig farming systems in Papua and West Papua. Sains Peternakan. 9(2): 88-99.

Iyai, D.A., Mulyadi, and B. Gobay. 2018. Trend analyses of economical and sociocultural options of Arfak tribe pig farmers on shaping pig farming development in Manokwari, West Papua-Indonesia. Jurnal Peternakan Sriwijaya. 4 (1): 54-65.

Kanis, E., A.F. Groen, and K.H. De Greef. 2003. Societal concerns about pork and pork production and their relationships to the production system. Journal of agricultural and Environmental Ethics. 16(2): 137-162.

Kijlstra, A. and I.A.J.M. Eijck. 2006. Animal 
health in organic livestock production systems: a review. NJAS-Wageningen Journal of Life Sciences. 54(1): 77-94.

Kruska, R.L., R.S. Reid, P.K. Thornton, and N. Henninger. 2003. Mapping livestockoriented agricultural production systems for the developing world. Agricultural Systems. 77(1): 39-63.

Lassen, J., P. Sandøe, and B. Forkman. 2006. Happy pigs are dirty!-conflicting perspectives on animal welfare. Livestock Science. 103(3): 221-230.

Muhanguzi, D., V. Lutwama, and F.N. Mwiine. 2012. Factors that influence pig production in central uganda-case study of Nangabo sub-county, Wakiso district. Veterinary World. 5(6): 346-351.

Ott, R.L. and M. Longnecker. 2001. An Introduction to Statistical Methods and Data Analisys. Nelson Education. Duxbury.

Pattiselanno, F., S.Y. Randa, D.A. Iyai, and A. Baaka. 2014. Indigenous pig management in West Papua (Highland Vs Coastal sites). Suiform Soundings. 40.

Phiri, R.E. 2012. Determination of Piggery business profitability in Balaka district in Malawi. Livestock Research for Rural Development. 24(8).

Plaza-bonilla, D., C. Cantero-martínez, J. Bareche, J. Luis, J. Lampurlanés, and J. Álvaro-fuentes. 2017. Field crops research do no-till and pig slurry application improve barley yield and water and nitrogen use efficiencies in rainfed mediterranean conditions?. Field Crops Research. 203: 74-85.

Rivai, R.S. dan I.S. Anugrah. 2011. Konsep dan implementasi pembangunan pertanian berkelanjutan di Indonesia. 29(1): 1325.

Smith, C.K. 2010. Raising Goats for Dummies. John Wiley \& Sons. New York.

Terry, J.P. and K. Khatri. 2009. People, pigs and pollution-experiences with applying participatory learning and action (PLA) methodology to identify problems of pig-waste management at the village level in Fiji. Journal of Cleaner Production. 17(16): 1393-1400.

Uwizeye, A., P.J. Gerber, C.I. Opio, G. Tempio, A. Mottet, H.P.S. Makkar, A. Falcucci, H. Steinfeld, and I.J.M. de Boer. 2019. Nitrogen flows in global pork supply chains and potential improvement from feeding swill to pigs. Resources, Conservation and Recycling. 146: 168179.

Wabacha, J.K., J.M. Maribei, C.M. Mulei, M.N. Kyule, K.H. Zessin, and W. OluochKosura. 2004. Health and production measures for smallholder pig production in Kikuyu division, central Kenya. Preventive Veterinary Medicine. 63 (3-4): 197-210.

Widayati, T.W., I. Sumpe, B.W. Irianti, D.A. Iyai, and S.Y. Randa. 2018. Faktor-faktor yang mempengaruhi produksi usaha ternak babi di Teluk Doreri Kabupaten Manokwari. Agrika. 12(1): 73-82. 